\title{
32 Informal workers and the state in India
}

\author{
Rina Agarwala
}

Informal employment arrangements, which include precarious wage employment and self-employment, have long served as a "fix" for capital to lower labour costs and skirt labour protections. They are not just a residual of a traditional economy destined to disappear with modernity nor a recent product of neoliberalism. Rather, informal employment always has fuelled and always will fuel modern capitalist production.

While informal employment has long persisted, informal workers' social relationships with the state, capital and formal workers have changed over time under varying regimes of capitalist accumulation. During the shift from agrarian to industrial capitalism, state regulations constituted a minority of formally protected labour, formally registered capital and a standard employment relationship while simultaneously retaining informal labour, now re-defined as an excluded, non-standard unprotected "other". This enabled capital to overtly hire formal labour while discreetly hiring informal labour. These moves divided the working class into formal workers organised within unions on the shop floor, and informal workers who were often excluded from such organisations.

During the recent shift from industrial to financial capitalism, capital has continued to exploit informal labour to ensure profitability. Now, however, states are retracting twentieth-century regulations that held capital responsible for labour, so unprotected informal labour is posited as an ideal, while formal labour is depicted as problematic. Private and public capital can overtly hire informal labour and decrease their reliance on formal labour.

Within this context, scholars have shown that informal workers (in both the Global North and the Global South) are organising to fight for redistribution and recognition. Their movements highlight the contradictory relationship of collaboration and contestation they hold with the state, capital and formal workers. Like formal workers, informal workers are launching what Karl Polanyi (1944) famously called "counter-movements" to resist the de-humanising effects of labour commodification (at the material and symbolic levels), and they often draw on union models of organisation. But informal workers' movements are also distinct from many formal workers' movements. First, they struggle for new labour protection regulations that offer some redistribution from capital to informal workers and fight for new economic policies that support informal 
workers' livelihoods, rather than punish them. These struggles target the state. Since informal workers operate outside the protective arm of the state and are unable to make demands under existing law, they wield their electoral power as mass and poor voters to attract state attention. ${ }^{1}$

Second, informal workers' movements struggle for what Nancy Fraser (2013) calls "emancipation" from earlier formal workers' movements that excluded certain races, genders and sub-classes - specifically, informal workers. Such exclusions led to dominant state narratives that devalued and punished informal labour. Informal workers, therefore, fight such narratives by demanding state recognition and valorisation as legitimate economic actors, as workers.

Informal workers' movements are at an infant stage and are constrained by the marketisation forces of the state and capital. But these challenges must not negate their significance in mobilising, organising, and enacting new state policies that reshape contemporary understandings of "labour" and "capital".

\section{The case of India}

While the state has long featured as a central actor in scholarship on Indian labour and development, informal workers have been absent. In the 1980s, Pranab Bardhan (1984) supplemented the classical political economy dyad of labour and capital with the Indian state as a "third actor" with its own interests, power base and collective action strategies. Debates followed on the Indian state's relations with other actors of the triad. Some argued the Indian state was so powerful, it eclipsed class politics between capital and labour (Rudolph and Rudolph 1987). Others argued that Indian capital pushed the Indian state to squeeze labour's power relative to capital, thereby weakening the state's power to discipline capital (Chibber 2003). Still others argued that politically affiliated labour unions in India are more militant and effective than independent unions (Teitelbaum 2011). The focus on labour within these debates remained limited to formal workers.

By the 1990s, academic discussions on state-society relations in India turned to the post-1980s upsurge in "new social movements" (NSM) that mobilised around ascriptive identities (caste, gender, indigeneity) or specific issues (land, environment, education) (Omvedt 1993). Rather than organising into class-based unions, NSMs mobilised as unregistered civic rights groups and/or registered NGOs. These movements of subaltern groups were lauded for exposing the patriarchy, casteism and ethno-centrism that undergirded many formal workers' movements. But this literature, too, ignored informal workers as politically salient.

Informal workers' absence in Indian scholarship on state-society relations is puzzling. Like formal workers, informal workers' exploitation forms a bedrock of state-supported capitalist accumulation (Luxemburg 1951). Over 90 per cent of the workforce in India is informal, including those self-employed in unregulated, small-scale enterprises and wage workers in large, formal enterprises, small informal enterprises and households. Like other identity groups, informal 
workers were excluded from formal labour's earlier movements for state protection. There is, therefore, no theoretical reason to omit informal workers from analyses of the state, labour and civic engagement. Rather, scholars' omission is based on an erroneous assumption that informal workers are not "real workers" interacting with capital or the state and are thus unorganisable.

Scholars' blindness to informal workers notwithstanding, Indian informal workers, since the 1970s, have been fighting for improved state relations that recognise and regulate their interactions with capital (Rose 1993; Bhatt 2006). Why do they target the state? Despite its multiple failings, the Indian state still determines economic and labour market policies, and it remains the expected deliverer of development, even among militant citizen groups (Sundar 2016). Moreover, for self-employed workers who do not have an employer, the state is a key driver of their ability to work, as well as their earnings and working conditions.

\section{The Indian state's contemporary project on informal work}

Since the 1980s, the Indian state has enacted several new projects to incorporate informality into its development agenda (see Agarwala 2019). While these changes are partly due to informal workers' demands, they also came alongside the state's expanding liberalisation efforts.

First, despite its refusal to guarantee protection for all workers, the Indian government has increasingly recognised informal workers as legitimate actors in its development agenda. In official statistics, although informal enterprises have long been acknowledged, the Indian government's National Sample Survey on Employment and Unemployment (NSS) counted individual informal workers for the first time only in 1999. ${ }^{2}$ During the 1990s and 2000s, the Indian government also set up a high-level committee to calculate income earned from informal employment and included informal workers' organisations in policy dialogues.

Second, unprotected informal labour in India has become the new ideal. Informal wage employment has grown in large, formally regulated firms in the private and public sectors. Between 1985 and 2011, the share of informal workers in registered factories increased from 12 per cent to 51 per cent (NSS 2012). Between 1999 and 2011, the share of informal workers in registered enterprises grew three times as fast as formal employment in registered enterprises (Ghose 2016). In 2011, the Indian government introduced a new category of workers, called "regular informal". These are workers who have an oral or written contract, but are not entitled to the minimum wages and the non-wage benefits (such as pensions, health care, and annual and sick leave) that formal workers receive. Between 1999 and 2011, the share of regular informal workers increased from 13 per cent to 18 per cent in the public sector and from 39 per cent to 50 per cent in the private sector. ${ }^{3}$ In many industries (including automobiles and garment manufacturing), informal and formal workers operate sideby-side, despite their unequal protections.

Finally, unprotected informal labour has now become the foundation of Indian employment growth in the non-agricultural sector. Since independence, 


\section{Rina Agarwala}

state development policies have sought to shift labour from agriculture to nonagricultural jobs. 2011 marked the first year the majority of Indians worked in non-agricultural jobs (at 56 per cent). Agricultural jobs had declined and nonagricultural jobs had grown enough to tip the balance in favour of a long-sought development ideal. Unlike most East Asian economies that drew on their literate workforce to fuel a large manufacturing sector, however, India's non-agricultural employment growth has come from services and construction, where jobs are notoriously informal and unprotected. (India's economic growth, therefore, has not been entirely "jobless", as is often claimed. Rather, the growth has relied on bad jobs.)

\section{Indian informal workers' struggles against the state}

Within this context, Indian informal workers across sectors (including construction, domestic work, street vending, waste-picking, tobacco manufacturing and garment manufacturing) have initiated innovative ways to improve state relations through new legislations that recognise and regulate informal employment relationships and seek to redistribute profit shares from capital to labour. Despite the expected challenges of implementation, new state legislations are seen by informal workers as essential to attaining dignity and arming workers with (at least) the threat of enforcement.

\section{Redistribution}

Since the 1970s, informal workers have used collective bargaining to improve legislation on wages and working conditions to fit multiple informal employment relationships. Home-based garment workers have fought to revise local minimum wage laws from time-based to piece-rates; self-employed street vendors have fought to gain legal access to public space for their businesses, free of police harassment; and waste picker cooperatives have attained exclusive garbage collection contracts from municipalities (Agarwala 2016).

Since the 1980s, informal workers have also used their power as mass voters to demand the state take responsibility for their welfare needs by enacting and implementing an innovative institution, called a "welfare board" (Agarwala 2013). ${ }^{4}$ Because informal workers are excluded from collective bargaining agreements, welfare boards aim to redistribute some profits from capital and the state to informal workers through the delivery of social protection benefits such as housing, education scholarships, health care clinics, funeral expenses and pensions. Such welfare boards that target informal workers, rather than formalising them, are unique to India. Currently, welfare boards are trade-specific. Most are tripartite, where state governments, employers and workers have representation and contribute funds. Employers' contributions come from a tax on production, while workers' contributions come from board membership dues. To register for board benefits, workers must prove their informal work status. Unions of informal workers have become essential to educating informal workers about 
welfare boards, providing the state with confirmation of workers' informal status, and pressurising the state to implement the benefits mandated by the boards and deliver the promised benefits.

Informal workers' struggles for new redistributive legislation have also drawn on the judicial activism that grew in India during the 1980s when civic groups partnered with the judicial branch to hold the legislative and executive branches accountable for socio-economic deprivations through constitutionally guaranteed rights-based claims using public interest litigation (PIL) (Agarwala 2018). After attaining new legislation that regulates and protects informal employment, informal workers have used PILs to hold the judiciary accountable for enforcing the executive and legislative branches to implement the laws.

Informal construction workers offer an important illustration of these redistribution struggles. They have organised at the national level to successfully force the national government to enact new legislation, including the 1996 Building and Other Construction Workers (Regulation of Employment and Conditions of Service) Act, which regulates informal employment conditions, and the Welfare Cess Act, ${ }^{5}$ which enacts the Construction Workers' Welfare Board. Subsequently, construction workers successfully used PILs to force all state governments to enact the welfare boards at the local levels. As with all welfare measures in India, construction workers' organisations must now expend substantial time holding governments accountable for implementing the benefits mandated by the boards and exposing state mishandling of the welfare funds.

Due to workers' efforts, construction workers' welfare boards have survived the government's recent attack on welfare boards in other sectors (at least at the time of writing). Construction boards remain one of the few institutions through which the swelling profits of builders can be redistributed to informal workers and to workers migrating across state lines. Through the tri-partite governing and funding structure of construction welfare boards, organisations have ensured the distribution of hundreds of thousands of identity cards to informal workers and the collection of hundreds of thousands of dollars for informal workers' welfare. Finally, organisations across the country have used the promise of immediate welfare benefits from the construction boards to organise thousands of new members.

Due to these important benefits and despite the implementation challenges of construction boards, informal workers continue to demand the creation of new welfare boards and the protection of existing welfare boards in other sectors. Some of the other welfare boards have provided self-employed workers (such as garment workers and domestic workers) with trade-specific inputs and tools. Others have aimed to provide generalised welfare to all informal workers across sectors (such as the 2008 Social Security Act for Unorganised Workers). These newer boards are, unfortunately, not tri-partite and many lacked a defined funding source from capital in their original design. But organisations of informal workers continue to rely on the promised benefits of these boards to mobilise new members, ensure state recognition of informal work, and hold the state responsible for some redistribution. 


\section{Recognition}

Indian informal workers have also fought to attain state recognition as workers and for their economic contributions. This has not been easy since many employers are unregistered (as in domestic work or small-scale manufacturing), or nonexistent (as for the self-employed), and work often occurs in non-traditional settings (as in the street or private homes). Informal workers' politics of recognition has spurred a distinct group-based identity that asserts the group's vulnerability, but fights for protections within that identity, rather than fighting to erase the identity by becoming formalised.

Struggles to incorporate informal workers into government statistics and attain new legislation that recognises, regulates and protects informal employment have helped cement state and public recognition of informal labour. As well, through their struggles for union registration and welfare boards, informal workers have attained state-sanctioned identity cards, which in turn offer informal workers state recognition of their work, even in the absence of employer recognition. Most recently, this recognition was afforded to domestic workers through the national approval of domestic workers' unions, despite the government's continuing refusal to enact protective legislations for domestic workers. Particularly striking have been self-employed garment workers' and waste pickers' demands for worker identity cards. To attain worker identity cards, these groups exposed the indirect profits the state and middle-class citizens (in addition to capital) make off their labour value (Agarwala 2016). Informal workers across sectors demand identity cards as essential to attaining legal affirmation of their work, dignity as workers, protection against police harassment, access to social benefits, and a platform to demand legal protection.

Indian informal workers' struggles for state redistribution and recognition have two noteworthy characteristics. First, to mobilise dispersed workers who live with blurred boundaries between work and home (with some working in their homes, and others living at their worksites), organisations have mobilised informal workers' class identities at the neighbourhood or worksite - rather than at the shop floor level. Importantly, the language of "citizenship", "space-based mobilisation" and "welfare demands on the state" has enabled informal workers" organisations to include subaltern groups (such as women and lower-caste members) involved in hidden forms of contract and self-employed work in homes and unregistered work sheds. In turn, this has enabled informal workers' struggles for state protection to include workers and occupations that had earlier been excluded from formal workers' movements.

Second, the effectiveness of informal workers' struggles is shaped by the political and economic context in which they operate, but not always in simple, expected ways. In some cases, such as waste picking and street vending, informal workers' ability to build relations with the municipal government is key. In other cases, such as construction and tobacco manufacturing, informal workers operating under competitive populist parties (even neoliberal) are more 
successful than those operating under single, hegemonic party rule (even when that party is left-wing) (Agarwala 2013).

\section{Next steps}

These findings yield important future research agendas. First, the regulation approaches commonly used to explain informal employment must be expanded. By highlighting informal workers as those operating outside protective labour regulation, scholars of the Global South have exposed the structural reasons why formal workers, employers and the state rely on informal work under capitalism - unregulated work fosters growth (Portes, Castells and Benton 1989; Breman and van der Linden 2014). However, these regulation approaches focus only on workers' exclusion from protective regulations, ignoring the punitive state regulations (such as denying access to space, criminalising work, enabling police harassment) under which informal workers operate. Regulation approaches also do not accommodate informal workers' efforts to establish new regulations that protect, regulate and recognise informal employment. Therefore, to leave more theoretical space to examine informal workers' budding movements, scholars must specify that informal workers are those not regulated or protected under traditional labour laws based on a formal employer-employee relationship.

Second, we need more comparative analyses on informal workers' struggles vis-à-vis the state in different locations and sectors. This may involve examining movements that are still at an infant stage and others that appear to be faltering. But ignoring them will only hinder our understanding of their potential and limits.

Finally, we need deeper research on how different states have established hegemonic models of liberalisation that feature informal workers and absolve capital of responsibility for labour, while still retaining legitimacy among their citizens. Only then can we examine the limits and contradictions of these state strategies and ultimately analyse the future of the world's workers.

\section{Notes}

1 See Chen (2014b) for a more in-depth discussion on the difference between punitive vs. protective legislation for and government responses to informal work.

2 The Self-Employed Women's Association (SEWA) and the WIEGO Network, with the ILO and the Delhi Group on Informal Sector Statistics advocated for a definition of informal employment.

3 Ajit Ghose, ICSSR National Fellow and Honorary Professor, Institute for Human Development, New Delhi, February 2017.

4 See Chapter 30 by Kamala Sankaran in this volume for a further discussion of the role of welfare boards in realising employer liability for informal workers.

5 A "cess" is a tax. In this case, the cess is collected from large construction companies to fund welfare for informal construction workers. 